\title{
PENGARUH BREAK EVEN POINT TERHADAP PENGANGGARAN LABA PADA PT KALBE FARMA, JAKARTA PERIODE 2012 - 2016
}

\author{
Irwan Suhartono
}

${ }^{1)}$ dosen universitas pamulang, email : $\underline{\text { Irwansuhartono65@gmail.com }}$

\section{ARTICLES INFORMATION \\ JURNAL SEKURITAS \\ (Ekonomi, Keuangan dan Investasi ) \\ Vol.1, No.3, Maret 2018 Halaman : $27-45$ \\ (c) LPPM \& Prodi Manajemen UNVERSITAS PAMULANG \\ ISSN (online) : 2581-2777 ISSN (print) : :2581-2696}

Keyword :

Kata kunci: $B E P$,

Perencanaan Laba

JEL. classification :

C33, G20, G23, N65

\section{Contact Author :}

PRODI MANAJEMEN UNPAM

JL.Surya Kencana No.1 Pamulang

Tangerang Selatan - Banten

Telp. (021) 7412566, Fax (021) 7412491 Email:

jurnalfinance.unpam@gmail.com
Penelitian ini dilakukan dengan tujuan Mengetahui Break Even Point pada PT. Kalbe Farma Tbk periode 2012 - 2016, Mengetahui Laba pada PT. Kalbe Farma Tbk periode 2012 2016, Mengetahui Pengaruh Break Even Point terhadap perencanaan laba pada PT. Kalbe Farma Tbk. Penelitian ini menggunakan desain penelitian studi kasus pada PT. Kalbe Farma Tbk, Jakarta. Pendekatan secara tabelaris, yaitu dengan cara menghitung jumlah penghasilan dan biaya pada berbagai tingkat atau valume penjualan/produksi dan Pendekatan secara aruthmatik. Data diperoleh dengan menggunakan teknik dokumentasi dan observasi. Analisis data menggunakan menggunakan perhitungan BEP rupiah, Analisis korelasi dan Koefisien Determinasi dan Uji Hipotesis.

Hasil Analisis sebagai berikut: Berdasarkan perhitungan statistic yang telah dilakukan, dilihat dari koefisien korelasi bahwa pengaruh Break Even Point terhadap laba mempunyai hubungan yang kuat (positif) serta pengaruh kuat, yaitu 0.80 . jika dilihat dari perhitungan uji t bahwa besar pengaruh antara Break Even Point terhadap Laba terdapat hubungan yang tinggi (positif), yaitu secara persial t hitung sebesar 2.31 sedangakan t tabel 2.70. maka Ha diterima yang berarti ada pengaruh antara Break Even Point terhadap perencanaan laba.

This research was conducted with the aim of Knowing Break Even Point at PT. Kalbe Farma Tbk period 2012 - 2016, Knowing Profit at PT. Kalbe Farma Tbk period 2012 - 2016, Knowing the influence of Break Even Point on profit planning at PT. Kalbe Farma Tbk. This research uses case study research design at PT. Kalbe Farma Tbk, Jakarta. Approach tablearis, that is by calculating the amount of income and cost at various levels or sales / production valence and aruthmatik Approach. Data were obtained by using documentation and observation technique. Data analysis using the calculation of BEP rupiah, Correlation Analysis and Coefficient of Determination and Hypothesis Testing.The results of the analysis as follows: Based on the calculation of statistics that have been done, seen from the correlation coefficient that the effect of Break Even Point on earnings have a strong relationship (positive) and strong influence, that is 0.80 . if seen from $t$ test calculation that big influence between Break Even Point to Earnings there is high correlation (positive), that is by $t$ calculate equal to 2.31 while $t$ table 2.70. then $\mathrm{Ha}$ is accepted which means there is influence between Break Even Point to profit planning. 


\section{A. Pendahuluan}

Perencanaan dan pengendalian laba merupakan proses yang ditujukan untuk membantu manajemen dalam melaksanakan fungsi - fungsi perencanaan dan pengendalian secara efektif. Perencanaan laba merupakan rencana kerja perusahaan untuk mencapai target laba yang telah ditentukan. Apalagi di Era globalisasi menjanjikan suatu peluang dan tantangan bisnis bagi suatu perusahaan, dimana dengan adanya era globalisasi akan dapat memperluas pasar produknya dan disisi lain keadaan tersebut akan memunculkan persaingan ketat dalam industri produk rumah tangga atau produk personal.

Dalam menghadapi era globalisasi yang dapat memperkatat persaingan bisnis maka perusahaan dalam perannya yakni manajemen dituntut untuk menjalankan perusahaan agar kekayaan yang menjadi tanggung jawabnya digunakan secara efektif dan efisien. Menghasilkan laba yang optimal merupakan salah satu cara untuk memenuhi tuntutan tersebut, mengingat perannya untuk bisa memuaskan pihakpihak yang berkepentingan.

Manajemen dituntut untuk menhasilkan keputusan-keputusan yang menunjang terhadap pencapain tujuan perusahaan serta mempercepat perkembangan perusahaan. Manajemen memerlukan suatu perencanaanuntuk perusahaan dalam mencapai tujuannya tersebut. Ukuran yang sering dipakai untuk menilai sukses tidaknya manajemen suatu perusahaan adalah laba yang diperoleh.

Pada umumnya kemampuan yang dimiliki oleh suatu perusahaan untuk menjual hasil produksinya adalah terbatas. Dengan demikian tidak ada perlunya membeli material, menghasilkan barang/jasa, mencari modal atau membeli mesin-mesin yang lebih besar dari pada kemampuan menjual. sehingga dapat dikatakan bahwa anggaran penjualan merupakan dasar dilakukannya aktifitas-aktifitas, dan pada umumnya anggaran penjualan disusun paling dahulu dari anggaran-anggaran lainnya.

Manajer perusahaan harus dapat membuat perencanaan secara terpadu atas semua aktifitas mencapai laba yang diharapkan. Dalam perencanaan maupun realisasinya manajer dapat memeperbesar laba melalui langkah-langkah berikut :

1. Menekan biaya operasional serendah mungkin dengan mempertahankan tingkat harga jual dan volume penjualan yang ada.

2. Menentukan tingkat harga jual sedemikian rupa sesuai dengan laba yang dikehendaki.

3. Meningkatkan volume penjualan sebesar mungkin. Ketiga langkah tersebut tidak dapat dilakukan secara terpisah atau sendiri sebab ketiganya mempunyai hubungan yang erat bahkan saling berkaitan.

Analisis Break even adalah suatu alat yang digunakan untuk mempelajari hubungan antara biaya tetap, biaya variabel, keuntungan dan volume penjualan (Bambang Riyanto, 2001:359). Dengan melakukan analisis break even manajemenakan memperoleh informasi tingkat penjualan minimal yang harus dicapai, agar tidak mengalami kerugian.

PT.Kalbe Farma, Tbk. Merupakan perusahaan yang melakukan berbagai upaya ke arah peningkatan volume penjualan dengan tujuan untuk meningkatkan 
keuntungan. Bertolak dari latar belakang diatas, maka peneliti tertarik untuk melakukan penelitian dengan mengambil judul: "Analisis Break Even Poin terhadap Perencanaan Laba pada PT Kalbe Farma, Tbk"

\section{B. Perumusan Masalah}

1. Bagaimana Break Even Point terhadap PT. Kalbe Farma Tbk periode $2012-2016$ ?

2. Bagaimana perencanaan laba terhadap PT. Kalbe Farma Tbk periode 2012 -2016 ?

3. Bagaimana pengaruh break even point terhadap perencanaan laba pada PT. Kalbe Farma Tbk periode 2012 - 2016 ?

\section{Tujuan Penelitian}

1. Untuk mengetahui Break Even Point pada PT. Kalbe Farma Tbk periode 2012- 2016

2. Untuk mengetahui Laba pada PT. Kalbe Farma Tbk periode 2012 - 2016

3. Untuk mengetahui Pengaruh Break Even Point terhadap perencanaan laba pada PT. Kalbe Farma Tbk

\section{Landasan Teori}

\subsection{Manajemen Keuangan}

\subsubsection{Definisi Manajemen Keuangan}

Menurut James C. Van Home, manajemen keuangan adalah aktivitas yang berhubungan dengan perolehan, pendanaan, dan pengolahan aktiva dengan beberapa tujuan menyeluruh.

Menurut Bambang Riyanto, Manajemen keuangan adalah keseluruhan aktifitas perusahaan yang berhubungan dengan usaha mandapatkan dan yang diperlukan gengan biaya yang minimal dan syarat - syarat yang paling menguntungkan beserta usaha untuk menggunakan dana tersebut seefisien mungkin.

Dari pengertian diatas, dapat ditarik beberapa kesimpulan bahwa manajemen keuangan berhubungan dengan tiga aktifitas (fungsi) utama :

a. Allocation of founds (aktivitas penggunaan dana) yaitu aktivitas untuk menginvestasikan dana pada berbagai aktiva.

b. Raising of Founds (aktivitas perolehan dana) yaitu aktivitas untuk mendapatkan sumber dana baik dari sumber internal perusahaan maupun sumber eksternal perusahaan, termasuk juga politik deviden.

c. Manajemen Assets (Aktivitas pengelolaan aktiva) yaitu setelah dana diperoleh dan dialokasikan dalam bentuk aktiva - aktiva harus dikelola seefisien mungkin.

\subsubsection{Fungsi Manajemen Keuangan}

Manajemen keuangan menurut Fred menjelaskan secara umum aktifitas manajer keuangan adalah:

1. Meramalkan dan merencanakan keuangan 
Seorang manjer keungan harus mampu berinteraksi dengan eksekutif lain dan bersama-sama merencanakan kegiatan apa saja yang harus dilakukan kedepan.

2. Keputusan permodalan, investasi dan pertumbuhan

Investasi dan pertumbuhan Manajer keuangan dituntut untuk mampu menghimpun dana yang dibutuhkan baik jangka pendek (keperluan modal kerja) maupun jangka panjang.

a. Melakukan pengendalian

Dalam menjalankan aktifitasnya manajer keuangan dituntut untuk mampu berinteraksi dengan eksekutif lain dalam menjalankan operasi perusahaan secara efisien, sehingga apabila terjadi penyimpangan masing-masing pihak dapat mengendalikan ke arah seperti yang telah direncanakan. Tanpa pengendalian kemungkinan kegagalan dalam pencapaian tujuan perusahaan sangat besar.

b. Hubungan dengan pasar modal

Kebutuhan akan modal dapat dicari dari berbagai alternative sumber dana dan salah satunya adalah dari pasar modal. Dalam hal ini manajer keuangan harus mampu berhubungan dengan pasar modal sehingga pencarian modal dari sumber ini dapat di penuhi.

\subsubsection{Tujuan Manajemen Keuangan}

Setiap perusahaan memiliki beberapa tujuan yang hendak dicapai baik tujuan jangka pendek maupun tujuan jangka panjang. Berikut beberapa tujuan perusahaan yang dirangkum dari pendapat beberapa ahli keuangan :

1. Memaksimalkan Nilai perusahaan.

2. Maksimalisasi laba.

3. Menciptakan kesejahteraan bagi stakeholder.

4. Menciptakan citra perusahaan.

5. Meningkatkan tanggung jawab social.

\subsection{Laporan Keuangan}

\subsubsection{Definisi Laporan Keuangan}

Laporan keuangan merupakan kewajiban suatu perusahaan untuk membuat dan melaporkannya pada suatu periode tertentu. Bahwa dengan adanya laporan keuangan menunjukan kondisi perusahaan saat ini. Menurut Munawir yang berjudul "Analisa Laporan Keuangan" menyatakan : "Laporan keuangan pada umumnya terdiri dari Neraca, Laporan Laba Rugi, dan Laporan Perubahan Modal aau Laba yang Ditahan, walaupun dalam prakteknya sering diikutsertakan beberapa daftar yang sifatnya untuk memperoleh kejelasan lebih lanjut. Misalnya, Laporan Perubahan Modal Kerja, Laporan Arus Kas Perhitungan Harga Pokok, merupakan daftar-daftar lampiran yang lain." 


\subsubsection{Jenis - Jenis Laporan Keuangan}

Laporan keuangan yaitu menggambarkan pos - pos keuangan perusahaan yang telah diperoleh dalam sebuah periode.

1. Neraca

Laporan keuangan yang menunjukkan kondisi keuangan perusahaan pada waktu tertentu. Neraca menyajikan dalam data historikal ativa yang merupakan sumber operasi perusahaan yang dijalankan, utang yaitu kewajiban perusahaan, dan modal dari pemegang saham perusahaan.

2. Laporan Laba Rugi

Keuangan yang berisikan informasi tentang keuntungan atau kerugian yang diderita oleh perusahaan dalam satu periode tertentu. Pada laporan ini menyajikan data pendapatan sebagai hasil usaha perusahaan dan bahan sebagai pengeluaran operasional perusahaan.

3. Laporan Perubahan Posisi Keuangan

Biasanya disebut daftar sumber dan penggunaan dana, menunjukkan asal kas diperoleh dan bagaimana digunakannya. Laporan perubahan posisi keuangna menyediakan latar belakang historis dari pola aliran dana. Laporan ini terbagi menjadi dua yaitu; Laporan Perubahan Modal Kerja dan Laporan Arus Kas. Laporan Perubahan Modal Kerja menyajikan data-data aktiva lancar dan utang lancar, sedangkan Laporan Arus Kas menyajikan data-data mengenai arus kas dari kegiatan operasional, kegiatan investasi, kegiatan keuangan/pembiayaan, dan saldo kas awal, serta saldo kas akhir.

4. Catatan dan laporan lain sebagai penjelasan bagi laporan keuangan

Catatan dan laporan lain merupakan bagian integal yang tak terpisahkan dari laporan keuangan. Catatan-catatan ini tergantung pada kebijakan akutansi yang digunakan pada waktu mempersiapkan laporan keuangan dan memberi tambahan. Misalnya, Laporan Harga Pokok Produksi, Laporan Perubahan Modal dan Laba Ditahan, Laporan Kegiatan Keuangan.

\subsection{Pendapatan}

\subsubsection{Definisi Pendapatam}

Menurut Ralph Estes (1996, hal.119) pendapatan adalah: "Arus masuk sumber daya kedalam suatu perusahaan dalam suatu periode dari penjualan barang atau hasil penjualan jasa, pendapat tidak mencakup sumber daya yang diterima dari sumber-sumber selain dari operasi, seperti penjualan aktiva tetap, penerbitan saham atua pinjaman".

\subsection{Perencanaan Laba}

Manajemen perusahaan merumuskan rencana yang tepat untuk mencapai tujuanm organisasi. Menentukan tujuan perusahaan termasuk dalam perencanaanyang dilakukan manajemen perusahaan. Salah satu perencanaan yang dilakukan manajemen yaitu perencanaan laba. Perencanaan laba lebih sering digunakan sebagai dasar dalam pengambilan keputusan investasi dan penilaian kerja 
manajemen suatu perusahaan untuk masa yang akan datang. Perencanaan laba atau penganggaran mempunyai manfaat bagio perusahaan yaitu:

a. Memberikan pendekatan yang terarah dalam pemecahan masalah.

b. Memaksa pihak manajemen untuk secara dini mengadakan penelaahan terhadap masalah yang dihadapi dan menanamkan kebiasaan pada organisasi untuk mengadakan telaah yang seksama sebekum mengambil suatu keputusan.

c. Menciptakan suasana organisasi yang mengarah pada pencapaian laba.

d. Merangsang peran serta mengkoordinasi rencana oprasi berbagai segmen dari keseluruhan organisasi sehimngga keputusan akhir dan rencan saling berkaitan.

e. Menawarkan kesempatan untuk menilai secara sistematik setiap segi atau aspek organisasi maupun untuk memeriksa serta memperbaharui kebijakan dan pedoman dasar secara berkala.

Perencanaan laba jangka panjang merupakan proses yang berkesinamngan untuk mengambil keputusan secara sistematik dan disertai dengan perkiraan terbaik mengenai keadaan dimasa mendatang, mengorganisasikan kegiatan yang diperlukan secara sistematik untuk melaksanakan keputusan. Dengan segala laba dan pertumbuhan yang diharapkan haruslah dipecah kedalam anggaran jangka pendek, agar dapat seperti penetapan tujuan dan target laba yang realistis serta cara untuk mencapainya, yang diupayakan manajemen untuk dicapai. Pada pokoknya tiga prosedur yang berbeda dapat digunakan dalam menetapkan sasaran laba :

1) Metode a prioriri : dimana sasaran laba yang diinginkan ditetapkan terlebih dahulu sebelum proses perencanaan.

2) Metode a posteriori : dimana sasaran laba ditetapkan sesudah perencanaan, dan sasaran tersebut akan merupakan hasil perencanaan itu sendiri.

3) Metode pragmatis : dimana pihak manajemen menggunakan standar laba tertentu yang telah teruji secara empiris dan didukung oleh pengalaman.

\subsection{Break Even Point}

\subsubsection{Definisi Break Even Point}

Break even point dapat diartikan suatu keadaan dimana dalam operasionalnya, perusahaan tidak memperoleh laba dan tidak menderita rugi ( penghasilan = total biaya ). Tetapi analisis break even point tidak hanya semata - mata untuk mengetahui keadaan perusahaan yang break even saja, akan tetapi analisis break even mampu memberikan informasi kepada pimpinan perusahaan mengenai berbagai tingkat volume penjualan, serta hubungannya dengan kemungkinan memperoleh laba menurut tingkat penjualan yang bersangkutan.

Menurut Drs. S. Munawir. Akuntan (2004:37) break even point adalah suatu analisa untuk menentukan tingkat penjualan yang harus dicapai 
oleh suatu perusahaan agar perusahaan tersebut tidak menderita kerugian tetapi juga belum memperoleh keuntungan.

Tujuan perusahaan pada umumnya adalah untuk memperoleh laba dan besar kecilnya laba yang dicapai akan merupakan ukuran kesuksesan manajemen dalam mengelola perusahaannya. Oleh karena itu manajemen harus mampu merencanakan dan sekaligus mencapai laba yang besar agar dapat dikatakan manajemen yang sukses.

Perencanaan perusahaan dapat dilakukan dengan berbagai cara, antara lain dengan program budget. Sebagian dari program budget berisi taksiran penghasilan yang akan diperoleh oleh biaya - biaya yang akan terjadi untuk memperoleh penghasilan tersebut dan akhirnya menunjukan laba yang akan dicapai.

1. Kalsifikasi Break Even Point

Menurut Drs. Bambang Riyanto (1995:360) dalam mengadakan analisis Break Even Point, digunakan asumsi - asumsi dasar sebagai berikut :

a. Biaya didalam perusahaan dapat dibagi dalam golongan biaya variabel dan tetap.

b. Besarnya biaya variabel secara totalitas berubah - berubah secara proposional dengan volume per unit tetap sama.

c. Besarnya biaya tetap secara totalitas tidak berubah meskipunada perubahan volume produksi/penjualan. Ini berarti bahwa biaya tetap perunitnya berubah - ubah karena adanya perubahan volume kegiatan.

d. Harga jual perunit tidak berubah selama periode analisis.

e. Perusahaan hanya memproduksi lebih dari satu macam produk, perimbangan penghjasilan penjualan masing - masing produk atau salesmixnya tetap konstan.

Menurut Drs. Bambang Riyanto metode yang tepat dilakukan untuk menentukan tingkat break even point antara lain :

1. Metode Grafis

2. Metode Trial and Error

3. Metode Alhabar

Adapun langkah - langkah yang harus dilakukan untuk memperoleh nilai Break Even Point :

1. Metode Grafis

Dalam metode grafis penentuan Break Even Point dengan membuat gambar break even. Dalam gambar tersebut akan nampak garis - garis biaya tetap, biaya total yang menggambarkan jumlah biaya tetap dan biaya variabel, dan garis penghasilan penjualan. Besarnya volume produksi/penjualan dalam unit nampak pada sumbu horizontal (sumbu $X$ ) dan besrnya biaya dan penghasilan penjualan akan nampak pada sumbu verical ( Sumbu $Y$ ). Gambar break even tersebut dapat ditentukan, yaitu pada titik dimana terjadi persilangan antara garis penghasilan penjualan dengan garis biaya total. Apabila dari titik tersebut kita tarik garis lurus vertical kebawah sumbu $\mathrm{X}$ akan nampak besranya break even dalam unit. Kalau dari titik itu ditarik garis lurus 
horizontal ke samping sampai sumbu $Y$, akan nampak besarnya break even dalam rupiah.

2. Metode Trial and Eror

Metode Trial and Error dapat dilakukan dengan menghitung keuntungan operasi dari suatu volume produksi/penjualan tertentu. Apabila perhitungan tersebut menghasilkan keuntungan maka diambil volume penjualan/produksi yang lebih rendah. Apabila dengan mengambil suatu volume penjualan tertentu, perusahaan menderita kerugian maka kita mengambil volume produksi/penjualan yang lebih besar. Demikian dilakukan seterusnya sehingga dicapai volume penjualan/produksi dimana penghasilan penjualan tepat sama dengan besarnya biaya total.

3. Metode Break even Aljabar

Perhitungan break even point dengan mengguanakn rumus aljabar dapat dilakukan dengan dua cara, yaitu :

a. Atas dasar unit

b. Atas dasar sales dalam rupiah

Adapun cara penentuan dapat dilakukan langkah - langkah sebagai berikut :

1. Atas dasar unit

Dari hasil penjualan dikurangi dengan biaya variabel merupakan sisa atau margin yang tersedia untuk menutup biaya tetap. Ditinjau dari persatuan produk atau barang yang dijual, tiap satuan barang memberikan sumbnagn atau kontribusi yang sama besarnya untuk menutup biaya tetap. Dalam keadaan break even labanya adalah nol, maka dengan membagi jumlah biaya tetap dengan margin persatuan barang akan diperoleh jumlah satuan barang yang harus dijual atau diproduksi sehingga perusahaan tidak menderita kerugian maupun memperoleh keuntungan. Secara matematis dapat dirumuskan :

Dimana :

$$
B E P(\text { unit })=\frac{F C}{P-V C}
$$

$\mathrm{BEP}=$ analisis titik impas (break even point)

FC = biaya tetap (fixed cost)

VC = Biaya variabel persatuan (variabel cost)

$\mathrm{P} \quad=$ hrga jual persatuan (price)

$\mathrm{S} \quad=$ jumlah penjualan (sales volume)

2. Atas dasar sales rupiah

Perhitungan break even point atas dasar sales rupiah akan menunjukan break even laba perusahaan sama dengan nol. Oleh karena itu dnegan membagi jumlah biaya tetap dengan margin income rationya, akan diperoleh tingkat penjualan (dalam rupiah) yang harus dicapai agar perusahaan tidak menderita kerugian atau memperoleh keuntungan. Margin income ratio merupakan ratioa margine income dengan hasil penjualannya. Sedangkan margin income adalah selisih antara hasil penjualan dengan biaya variabel.

$$
B E P \text { rupiah }=\frac{F C}{1-\frac{V C}{P}}
$$




\section{E. Metodologi}

Dalam penelitian ini penulis menggunakan metode analisis regrasi. Menurut Sambas Ali dan Maman Abdurahman (2007:187) Analisis regerasi dipergunakan untuk mengetahui hubungan antara dua variabel atau lebih, terutama untuk menelusuri pola hubungan yang modelnya belum diketahui dengan sempurna atau untuk mengetahui bagaimana variasi dari beberapa variabel independen mempengaruhi variabel dependen dalam suatu fenomena yang kompleks. Beberapa Analisis yang digunakan adalah:

\section{Analisis Statistik Deskriptif}

Statistik Deskriptif yaitu statistik yg digunakan untuk menganalisis data dengan mendeskripsikan atau menggambarkan data yg telah terkumpul sebagaimana adanya tanpa bermaksud membuat generalisasi hasil penelitian.

\section{Analisis Korelasi}

Menurut Danang Sunyoto (2013:112) analisis korelasi adalah bagian integral dalam peramalan peramalan disini bukanlah berartiseperti meramalkan nasib tanpa data, tetapi berdasarkan data yang diolah dengan cara statistik yang kemudian menarik kesimpulan. Sedangkan koefisien korelasi merupakan suatu angka yang menunjukkan sebagai hal nya rata rata, standar deviasi, erat tidaknya hubungan data yang satu dengan data yang lain. Besar koefisien korelasi $(r)$ antara -1 sampai dengan kriteria sebagai berikut.

a) Jika $r=I$, hubungan $X$ dan $Y$ sempurna dan positif (mendekati) yaitu hubungan sangat kuat dan positif

b) jika $r=I$, hubungan $X$ dan $Y$ adalah sempura dan negatif (mendekati - 1 yaitu hubungan sangat kuat dan negatif)

c) Jika $r=0$, maka hubungan $X$ dan $Y$ lemah, dianggap tidak memiliki hubungan Persamaan umum koefisien korelasi sebagai berikut:

$$
\mathrm{r}=\quad \begin{aligned}
& n \sum X Y-\left(\sum X\right)\left(\sum Y\right) \\
& \sqrt{n \sum X^{2}}-\left(\sum X\right)^{2} x n\left(\sum Y^{2}\right)-\left(\sum Y\right)^{2}
\end{aligned}
$$

Keterangan :

$r=$ koefisien korelasi

$Y=$ Jumlah $Y$

$\mathrm{n}=$ Jumlah tahun

$X^{2}=$ Jumlah kuadrad hasil $X$

$\mathrm{X}=$ Jumlah $\mathrm{X}$ $\mathrm{Y}^{2}=$ Jumlah Kuadrad hasil $Y$

\section{Koefisien Determinasi}

Koefisien determinasi berfungsi untuk mengetahui besarnya pengaruh antara break even point terhadap laba pada PT Kalbe Farma, Tbk. Selanjutnya untuk melihat 
berapa besar variabel $\mathrm{X}$ berperan terhadap variabel $\mathrm{Y}$, maka digunakan rumus determinasi sebagai berikut.

$$
\mathrm{Kd}=\mathrm{r}^{2} \times 100 \%
$$

Keterangan: $-\mathrm{Kd}=$ koefisien determinasi

$$
r=\text { koefiien }
$$

\section{Uji Signifikasi}

Menurut Sambas Ali Muhidin dan Maman Abdurrahman (2007:103) tingkat signifikasi menunjukkan probabilitas atau peluang kesalahan yang ditetapkan peneliti dalam mengambilkeputusan untukmenolak atau mendukung hipotesis 0 . Seperti hal nya tingkat kepercayaan, tingkat signifikasi juga dinyatakan dalam persen. Misalnya, ditetapka tingkat signifikasi 0.05 atau 0.10. Artinya, keputusan peneliti untuk menolak atau mendukung hipotesis 0 memiliki probabilitas kesalahan sebesar $5 \%$ atau $10 \%$. Maka penulis melakukan uji hiotesis dengan langkah-langkah sebagai berikut:

Dinyatakan

$X=$ Break Even Point dan $Y=$ Laba

$\mathrm{HO}=\beta=0$ (Tidak ada pengaruh yang signifikan antara variabel $X$ dan $Y$

$\mathrm{HI}=\beta=0$ (ada pengaruh yang signifikan antara variabel $X$ dan $Y$

Keterangan: Terima $\mathrm{HO}$ jika t hitung $<\mathrm{t}$ tabel. Tolak $\mathrm{HO}$ jika t hitung $>\mathrm{t}$ tabel

\section{thitung=}

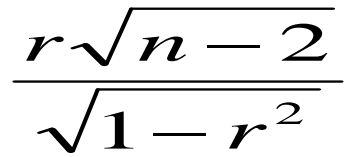

$$
\text { Keterangan } \quad \begin{aligned}
: \mathrm{t} & =\mathrm{t} \text { hitung hasil Observasi } \\
\mathrm{r} & =\text { Koefisien korelasi } \\
\mathrm{n} & =\text { Jumlah Sampel }
\end{aligned}
$$

\section{F. Hasil dan Pembahasan}

1. Pembahasan Masalah

a. Break Even Point Pada PT Kalbe Farma

Dalam menentukan Break Even Point, sebelumnya biaya digolongkan menjadi biaya variabel dan biaya tetap. Break Even Point dihitung berdasarkan pada laporan keuangan perusahaan selama periode penelitian yaitu dari tahun 2012 sampai dengan tahun 2016. Berikut disajikan Laporan Keuangan PT Kalbe Farma, Tbk.

\section{PT Kalbe Farma, Tbk}

\begin{tabular}{|c|l|l|l|l|l|}
\hline uraian & 2012 & 2013 & 2014 & 2015 & 2016 \\
\hline
\end{tabular}




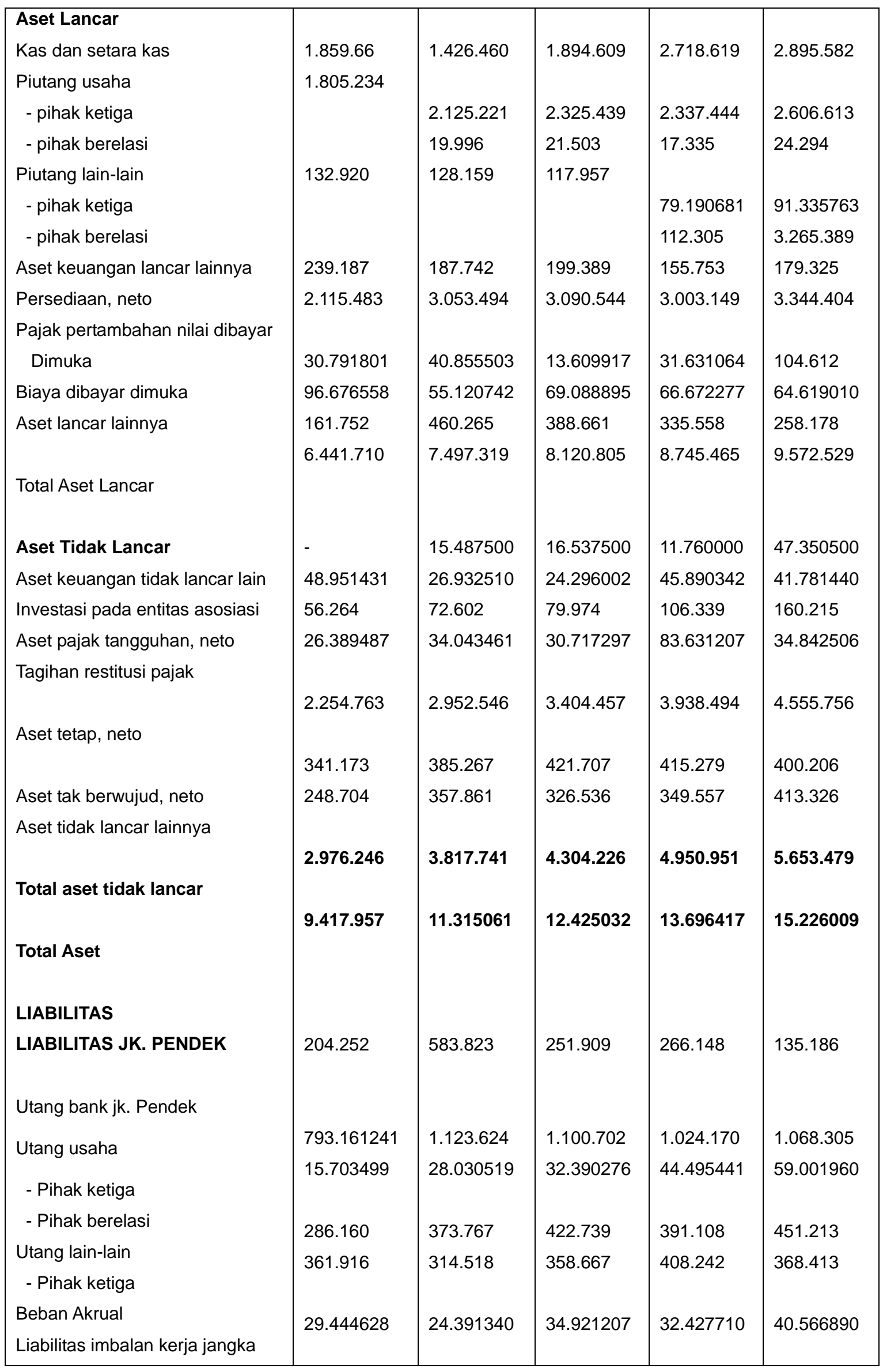




\begin{tabular}{|c|c|c|c|c|c|}
\hline Pendek & 195.836 & 186.953 & 184.590 & 197.459 & 180.958 \\
\hline Utang pajak & - & - & - & - & 12.208333 \\
\hline Bagian jangka pendek dari: & 293.784 & 91.344 .366 & - & 1.829 .302 & 1.298 .175 \\
\hline - Utang Bank & & & & & \\
\hline - Utang sewa pembiayaan & 1.891 .617 & 2.640 .590 & 2.385 .920 & 2.365 .880 & 2.317.161 \\
\hline Total liabilitas jk. pendek & & & & & \\
\hline LIABILITAS JK. PANJANG & & & & & \\
\hline Pinjaman jk. Panjang & & & & & \\
\hline Setelah dikurangi dengan & - & - & 44.219 & 127.727 & 132.240 \\
\hline bagian jk. Pendek & 78.356 .010 & - & - & 3.205872 & 2.176 .009 \\
\hline - Utang bank & 10.932 .346 & 11.931 .480 & 12.978815 & 6.602 .342 & 581.578 \\
\hline - Utang sewa pembiayaan & & & & & \\
\hline Liabilitas pajak tangguhan, neto & 143.685 & 162.581 & 164.437 & 254.715 & 300.201 \\
\hline Liabilitas imbalan kerja jangka & - & - & - & - & 9.800 .000 \\
\hline Panjang & 154.695712 & 174513285 & 221636516 & 392250903 & 445000282 \\
\hline Utang lain jk. Panjang pihak ke3 & 2.046.313 & 2.815 .103 & 2.607 .556 & 2.758 .131 & 2.762.162 \\
\hline Total Liabilitas jangka panjang & & & & & \\
\hline TOTAL LIABILITAS & & & & & \\
\hline EKUITAS & & & & & \\
\hline Ekuitas yang dapat & & & & & \\
\hline Diatribusikan kepada pemilik & & & & & \\
\hline Entitas induk & & & & & \\
\hline Modal saham- nilai nominal & & & & & \\
\hline $\begin{array}{c}\mathrm{Rp} 10 \text { persaham modal } \\
\text { dasar- } 85.000 .000 .000 \text { saham }\end{array}$ & 507800 & & 468751 & 468751 & 168751 \\
\hline Modal dapat ditempatkan dan & $(32.317)$ & & $(34.118)$ & $(34.118)$ & $(34.118)$ \\
\hline disetor penuh- 46.857.122.110 & (3.069) & (34.118) & (3.074) & 777.244 & 32.791 \\
\hline Tambahan modal disetor, neto & & $(3.0 / 0)$ & & & \\
\hline Selisih transaksi dengan & 77.133 .124 & & 113.667 & 134.314 & 154.356 \\
\hline kepentingan non pengendali & 7.173 .606 & 94.472 .405 & 8.787.330 & 9.872 .083 & 11.261148 \\
\hline Saldo laba & & 7.538 .115 & & & \\
\hline $\begin{array}{l}\text {-telah ditentukan penggunanya } \\
\text {-belum ditentukan }\end{array}$ & 3.337 .783 & 36.450368 & 40.008270 & 62.386164 & 56.687535 \\
\hline Penghasilan komperehensif lain & 14.846 .567 & & 9.459 .173 & 4.725 .655 & 32.825755 \\
\hline Selisih kurs atas penjabaran LK & & 7.040 .421 & & & \\
\hline Laba belum direalisasi dari aset & - & & - & $(43.796)$ & $(63.177)$ \\
\hline keuangan tersedia untuk dijual & & $\begin{array}{l}- \\
-\end{array}$ & & & \\
\hline Kerugian akruial atas liabilitas & 7.054.054 & & 9.382 .023 & 10.465122 & 11.909264 \\
\hline imbalan kerja jk panjang, neto & 317.589 & $\begin{array}{l}8.108 .241 \\
391.716\end{array}$ & 435.452 & 473.163 & 554.582 \\
\hline
\end{tabular}


ISSN (online) : 2581-2777 \& ISSN (print) : 2581-2696

\begin{tabular}{|l|l|l|l|l|l|}
\hline $\begin{array}{l}\text { Sub total } \\
\text { Kepentingan non pengendali }\end{array}$ & 7.371 .643 & 8.499 .957 & 9.817 .475 & 10.938285 & 12.463847 \\
Ekuitas, neto & 9.417 .957 & 11.315061 & 12.425032 & 13.696417 & 15.226009 \\
$\begin{array}{l}\text { TOTAL LIABILITAS DAN } \\
\text { EKUITAS }\end{array}$ & & & & & \\
\hline
\end{tabular}

Laporan Posisi

PT. Kalbe Farma, Tbk

LAPORAN LABA RUGI 


\begin{tabular}{|c|c|c|c|c|c|}
\hline $\begin{array}{l}\text { Penjualan Bersih } \\
\text { Beban Penjualan } \\
\text { - Behan Baku } \\
\text { - Tenaga Kerja } \\
\text { - Overheads } \\
\text { - Barang Jadi } \\
\text { Laba Kotor }\end{array}$ & $\begin{array}{r}13.363 .405 \\
(7.102 .971) \\
2.403 .315 \\
111.243 .514 \\
85.424 .138 \\
4.973 .083 \\
6.533 .434 \\
\end{array}$ & $\begin{array}{r}16.002 .131 \\
(8.323 .018) \\
3.026 .162 \\
187.734 .400 \\
117.678 .618 \\
5.680 .353 \\
7.679 .113 \\
\end{array}$ & $\begin{array}{r}17.368 .533 \\
(8.892 .737) \\
3.774 .890 \\
167.122 .368 \\
239.994 .644 \\
5.338 .139 \\
\mathbf{8 . 4 7 0 . 7 6 9} \\
\end{array}$ & $\begin{array}{r}17.887 .464 \\
(9.295 .887) \\
3.676 .125 \\
232.000112 \\
260106.236 \\
5.335 .922 \\
\mathbf{8 . 5 9 1 . 5 7 7} \\
\end{array}$ & $\begin{array}{r}19.374 .231 \\
(9.886263) \\
3.915 .076 \\
237.607269 \\
184.623319 \\
5.660 .821 \\
\mathbf{9 . 4 8 7 . 9 6 8} \\
\end{array}$ \\
\hline $\begin{array}{l}\text { Beban usaha } \\
\text { Penjualan dan Pemasaran } \\
\text { - Gaji dan Upah } \\
\text { - Iklan } \\
\text { - Penyusutan } \\
\text { - Royalti } \\
\text { - Tunjangan } \\
\text { - Perbaikan \& Pemeliharaan } \\
\text { - Listrik, Air \& Gas } \\
\text { - Pos dan Telekomunikasi } \\
\text { - perjalanan dinas } \\
\text { Umum dan Administrasi } \\
\text { Jumlah beban usaha }\end{array}$ & $\begin{array}{r}(3.573 .502) \\
845.768 .293 \\
1.203 .197 \\
70.282 \\
104.094 .391 \\
31.019 .24 \\
7.194 .103 \\
28.173 .949 \\
220.637 .064 \\
(651.417) \\
4.224 .515\end{array}$ & $\begin{array}{r}(4.320 .406) \\
989.687 .189 \\
1.411 .588 \\
88.420 .472 \\
116.190 .938 \\
33.013 .950 \\
40.486 .155 \\
22.128 .920 \\
30.841 .317 \\
261.664 .553 \\
(854.624) \\
5.175 .030\end{array}$ & $\begin{array}{r}(4.770 .129) \\
1.061 .578 \\
1.476 .148 \\
112.579 .842 \\
137.962 .935 \\
38.484 .318 \\
47.076 .053 \\
27.228 .395 \\
32.634 .625 \\
309.129 .601 \\
(1.100 .917) \\
5.871 .046\end{array}$ & \begin{tabular}{r|}
$(4.998 .581)$ \\
1.119 .240 \\
1.528 .983 \\
122.721924 \\
147.655851 \\
25.902 .661 \\
49.065 .585 \\
28.244 .265 \\
31.713 .435 \\
277.973049 \\
$(1.123 .215$ \\
6.121 .796
\end{tabular} & $\begin{array}{r}(5.351 .961) \\
1.138 .608 \\
1.747 .076 \\
116.653623 \\
161.194937 \\
47.565 .260 \\
51.457 .765 \\
26.728 .552 \\
37.465 .504 \\
262.716371 \\
(1.205 .541) \\
6.377 .502\end{array}$ \\
\hline Laba Usaha & 2.308 .515 & 2.504 .083 & 2.599 .750 & 2.469 .781 & 3.110 .466 \\
\hline $\begin{array}{l}\text { Pendapatan (beban) lain-lain } \\
\text { Laba penjualan aset tetap } \\
\text { Pendapatan bunga } \\
\text { Beban bunga } \\
\text { Laba selisih kurs- bersih } \\
\text { Uang pesangon } \\
\text { Pendapatan lainnya -bersih } \\
\text { Jumlah(beban)/pendapatan } \\
\text { bersih }\end{array}$ & $\begin{array}{l}74.539 \\
(4.709)\end{array}$ & $\begin{array}{r}21.261 \\
90.073 \\
(14.391) \\
529.460 \\
- \\
56.072 \\
\\
68.439\end{array}$ & $\begin{array}{r}36.016 \\
63.308 \\
(38.382) \\
13.605 \\
- \\
91.296 \\
165.843\end{array}$ & $\begin{array}{r}13.356 \\
101.334 \\
(9.958) \\
41.881 \\
- \\
104.496 \\
\\
\\
251.109\end{array}$ & $\begin{array}{r}6.446 \\
132.334 \\
(18.035) \\
- \\
- \\
45.976 \\
166.721\end{array}$ \\
\hline $\begin{array}{l}\text { badan } \\
\text { Beban (manfaat) Pajak } \\
\text { penghasilan badan } \\
\text { - Kini } \\
\text { - Tangguhan }\end{array}$ & $\begin{array}{r}2.378 .345 \\
\\
543.399 \\
(10.481)\end{array}$ & $\begin{array}{r}2.572 .523 \\
\\
617.409 \\
(15.339)\end{array}$ & $\begin{array}{r}648.434 \\
(6.324)\end{array}$ & $\begin{array}{l}681.307 \\
(18.120)\end{array}$ & $\begin{array}{l}793.758 \\
(53.454)\end{array}$ \\
\hline $\begin{array}{l}\text { Jumlah Beban } \\
\text { Laba bersih }\end{array}$ & $\begin{array}{r}532.918 \\
1.845 .427\end{array}$ & $\begin{array}{r}602.070 \\
1.970 .453\end{array}$ & $\begin{array}{r}642.110 \\
2.123 .483\end{array}$ & $\begin{array}{r}663.187 \\
2.057 .694\end{array}$ & $\begin{array}{r}740.304 \\
2.636 .883\end{array}$ \\
\hline $\begin{array}{l}\text { Laba usaha persaham (Rupiah } \\
\text { penuh) } \\
\text { Laba bersih persaham (Rupiah } \\
\text { penuh) }\end{array}$ & 1.845 .427 & 1.970 .453 & 2.123 .483 & 2.057 .694 & 2.636 .883 \\
\hline
\end{tabular}

Berikut rekapitalisasi biaya tetap dam biaya variabel dari tahun 2012 sampai 2016:

Tabel 4.1

PT Kalbe Farma, Tbk

REKAPITULASI BIAYA

TAHUN 2012 - 2016 


\begin{tabular}{|c|c|c|c|}
\hline Tahun & Biaya Tetap & Biaya Variabel & Penjualan \\
\hline 2012 & 1.355 .336 .355 & 204.044 .050 & 13.363 .405 \\
\hline 2013 & 1538.845 .077 & 34.119 .533 & 16.002 .131 \\
\hline 2014 & 707.634 .095 & 416.230 .041 & 17.368 .533 \\
\hline 2015 & 685.924 .993 & 501.118 .395 & 17.887 .464 \\
\hline 2016 & 706.667 .686 & 431.806 .485 & 19.374 .231 \\
\hline
\end{tabular}

\section{Tabel 4.2}

\section{Reakapitulasi Biaya Tetap dan Biaya Variabel}

\begin{tabular}{|l|r|r|r|r|r|}
\hline \multicolumn{1}{|c|}{ Biaya Variabel } & \multicolumn{1}{c|}{$\mathbf{2 0 1 2}$} & \multicolumn{1}{c|}{$\mathbf{2 0 1 3}$} & $\mathbf{2 0 1 4}$ & $\mathbf{2 0 1 5}$ \\
\hline Bahan Baku & 2.403 .315 & 3.026 .162 & 3.774 .890 & 3.676 .125 & 3.915 .076 \\
\hline Tenaga Kerja & 111.243 .514 & 187.734 .400 & 167.122 .368 & 232.000 .112 & 237.607 .269 \\
\hline Overhead & 85.424 .138 & 117.678 .618 & 239.994 .644 & 260.106 .236 & 184.623 .319 \\
\hline Barang jadi & 4.973 .083 & 5.680 .353 & 5.338 .139 & 5.335 .922 & 5.660 .821 \\
\hline Total & $\mathbf{2 0 4 . 0 4 4 . 0 5 0}$ & $\mathbf{3 4 . 1 1 9 . 5 3 3}$ & $\mathbf{4 1 6 . 2 3 0 . 0 4 1}$ & $\mathbf{5 0 1 . 1 1 8 . 3 9 5}$ & $\mathbf{4 3 1 . 8 0 6 . 4 8 5}$ \\
\hline
\end{tabular}

\begin{tabular}{|l|r|r|r|r|r|}
\hline \multicolumn{1}{|c|}{ Biaya Tetap } & \multicolumn{1}{|c|}{$\mathbf{2 0 1 2}$} & \multicolumn{2}{l|}{$\mathbf{2 0 1 3}$} & $\mathbf{2 0 1 5}$ & $\mathbf{2 0 1 6}$ \\
\hline Gaji dan Upah & 345.768 .293 & 989.687 .189 & 1.061 .578 & 1.119 .240 & 1.138 .608 \\
\hline Iklan & 1.203 .197 & 1.411 .588 & 1.476 .148 & 1.528 .983 & 1.747 .076 \\
\hline Penyusutan & 70.232 .198 & 83.420 .472 & 112.579 .842 & 122.721 .924 & 116.653 .623 \\
\hline Lembur, Bonus & 104.094 .391 & 116.190 .938 & 137.926 .935 & 147.655 .851 & 161.194 .937 \\
\hline Tunjangan & 31.019 .244 & 33.013 .950 & 38.484 .318 & 25.902 .661 & 47.565 .260 \\
\hline Perbaikan & & & & & \\
\hline Listrik & 36.963 .916 & 40.486 .155 & 47.076 .053 & 49.065 .585 & 51.457 .755 \\
\hline Pos \& Telekom & 28.173 .949 & 30.841 .317 & 32.634 .625 & 31.713 .435 & 37.465 .504 \\
\hline Perjalanan Dinas & 220.637 .064 & 261.664 .553 & 309.129 .601 & 277.973 .049 & 262.716 .371 \\
\hline & & & & & \\
\hline
\end{tabular}




\begin{tabular}{|l|l|l|l|l|l|}
\hline Total & 1.355 .336 .355 & 1538.845 .077 & 707.634 .095 & 685.924 .993 & 706.667 .686 \\
\hline
\end{tabular}

Break Even Point (dalam rupiah) nilai pendapatan di tahun 2012 - 2016

BEP

(dalam rupiah)

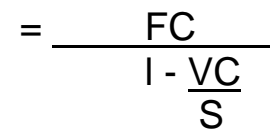

$\begin{array}{rlll}\text { Ket: FC } & \text { : Biaya Tetap } & \mathrm{S} & \text { : Volume Penjualan } \\ \text { VC } & \text { : Biaya Variabel } & & \end{array}$

- Break Even Point di tahun 2012

BEP

(dalam rupiah)

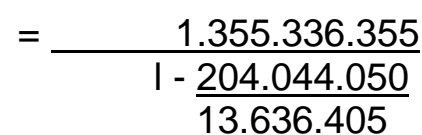

$=\underline{1.355 .336 .355}$

14

$=$ Rp. 90.355 .757

Break Even Point perusahaan ditahun 2012 adalah pada posisi nilai pendapatan sebesar Rp. 90. 355.757

- Break Even Point di tahun 2013

BEP

(dalam rupiah)

$$
\begin{aligned}
& =\frac{1.583 .845 .077}{I-\frac{314.119 .533}{16.002 .131}} \\
& =\frac{1.583 .845 .077}{19} \\
& =\text { Rp. 83.360.267 }
\end{aligned}
$$

Break Even Point perusahaan ditahun 2013 adalah pada posisi nilai pendapatan sebesar Rp. 83.360.267, pada tahun ini break even point mengalami penurunan karena kenaikan biaya variabel, biaya tetap dan penjualan yang tinggi.

- Break Even Point di tahun 2014

BEP

(dalam rupiah)

$$
\begin{aligned}
& =\frac{707.634 .095}{I-\frac{416.230 .041}{17.368 .533}} \\
& =\frac{707.634 .095}{23} \\
& =\text { Rp. 30.766.669 }
\end{aligned}
$$

Break Even Point perusahaan ditahun 2014 adalah pada posisi nilai pendapatan sebesar Rp. 30.766.669, pada tahun ini break even poin juga mengalami penurunan drastis dikarenakan penurunan di biaya tetap dan kenaikan dibiaya variabel dan volume penjualan 
- Break Even Point di tahun 2015

BEP

(dalam rupiah)

$$
\begin{aligned}
& =\frac{685.924 .993}{1-\frac{501.118 .395}{17.887 .464}} \\
& =\frac{685.924 .993}{27} \\
& =\text { Rp. } 25.404 .629
\end{aligned}
$$

Break Even Point perusahaan ditahun 2015 adalah pada posisi nilai pendapatan sebesar Rp. 25.404.629. pada tahun ini PT Kalbe mengalami penurunan break even point lagi dikarenakan penurunan di biaya tetap dan kenaikan dibiaya variabel dan volume penjualan.

- Break Even Point di tahun 2016

BEP

(dalam rupiah)

$$
\begin{aligned}
& =\frac{706.667 .686}{1-\frac{431.806 .485}{19.374 .231}} \\
& =\frac{706.667 .686}{21} \\
& =\text { Rp. 33.650.842 }
\end{aligned}
$$

Break Even Point perusahaan ditahun 2016 adalah pada posisi nilai pendapatan sebesar Rp. 33.650.842. PAda tahun ini break even point mengalami kenaikan dibandingkan tahun sebelumnya dikarenakan kenaikan biaya tetap.

4.2.2 Perencanaan Laba di PT Kalbe Farma, Tbk

Perencanaan Laba di PT Kalbe Farma, Tbk berdasarkan data tahun 2012 sampai dengan 2016 dengan menghitung Break Even Poin (Rupiah) dan menghitung Laporan laba rugi berdasarkan hasil penjualan yang dicapai setiap tahunnya.

Maka dapat dihasilkan perhitungan tersebut disajikan pada data yang telah diolah sebagai berikut:

PT KALBE FARMA Tbk

REKAPITULASI PERBANDINGAN BREAK EVEN POINT, HASIL PENJUALAN DAN LABA OPERASI PERUSAHAAN

Tahun 2012 - 2016

\begin{tabular}{|c|c|c|c|}
\hline Tahun & Hasil Penjualan & Laba Usaha & BEP \\
\hline 2012 & 13.363 .405 & 2.308 .515 & 90.355 .757 \\
\hline
\end{tabular}




\begin{tabular}{|l|l|l|l|}
\hline 2013 & 16.002 .131 & 2.504 .083 & 83.360 .267 \\
\hline 2014 & 17.363 .533 & 2.599 .750 & 30.766 .669 \\
\hline 2015 & 17.887 .464 & 2.969 .781 & 25.404 .629 \\
\hline 2016 & 19.374 .231 & 3.104 .466 & 33.650 .842 \\
\hline
\end{tabular}

Berdasarkan pada data diatas terdapat hasil penjualan rendah dengan laba yang tidak terlalu tinggi, namun perusahaan dapat membuktikan perencanaan penjualan dari tahun ke tahun menghasilkan penjualan yang bagus.

\subsubsection{Pengaruh Break Even point terhadap perencanaan Laba}

Untuk membuktikan adanya pengaruh Break Even Point terhadap perencanaan Laba, maka dilakukan Uji Analisis Statistik sebagai berikut:

$$
\begin{array}{ll}
r= & \text { Analisis Korelasi } \\
r= & \frac{n \sum X Y-\left(\sum X\right)\left(\sum Y\right)}{\sqrt{n \sum X^{2}-\left(\sum X\right)^{2} \times n\left(\sum Y^{2}\right)}-\left(\sum Y\right)^{2}} \\
r= & \frac{5.124 .649-(734)(840)}{\sqrt{5 \times 109.270}-538756 \times 5(142.958)-(705600)} \\
r= & \frac{623.245-616.560}{\sqrt{546.350-538.756 x 714790-705.600}} \\
r= & \frac{6.685}{\sqrt{69.788 .860}} \\
& \frac{6.354}{8.850}
\end{array}
$$

Jadi, $r=0.80$ artinya $X$ mempunyai pengaruh yang kuat terhadap variabel $Y$

\subsubsection{Koefisien Determinasi}

Menghitung koefisien determinasi, yaitu untuk mengetahui seberapa besar presentase pengaruh Break Even Point terhadap perencanaan laba, yaitu sebagai berikut:

$\mathrm{KD}=\mathrm{r}^{2} \times 100 \%$

$\mathrm{KD}=0.64 \times 100 \%$

$\mathrm{KD}=64 \%$

Berarti 64\% merupakan variasi dari variabel BEP dalam menjelaskan laba adalah $64 \%$ dan sisanya $36 \%$ dijelaskan oleh faktor lain yang tidak diteliti.

\subsubsection{Pengujian Hipotesis}

Nilai t hitung dengan formula sebagai berikut :

$$
\text { thitung }=\frac{r \sqrt{n-2}}{\sqrt{1-r^{2}}}
$$




$$
\begin{aligned}
& =\frac{0.80 \sqrt{3}}{\sqrt{1-0.64}} \\
& =\frac{0.80 \times 1.732}{\sqrt{0.36}} \\
& =\frac{1.386}{0.6}=2.31
\end{aligned}
$$

Hipotesis ini dilakukan dengan menentukan pengujian dengan memperhatikan derajat bebas $(\mathrm{db}=\mathrm{n}-2)$ dan tingkat $\alpha$ yang digunakan, pengujian ini menggunakan rumus:

$$
\begin{array}{rll}
\text { tabel } & = & \mathrm{t}(\mathrm{a}) \cdot \mathrm{db} \\
& = & \mathrm{t}(0.69) \cdot 3 \\
& = & 2.07
\end{array}
$$

Dari pengujian hipotesis diatas bahwa $t$ hitung $>\mathrm{t}$ tabel. maka $\mathrm{Ha}$ diterima yang berarti ada pengaruh antara Break Even Point terhadap perencanaan laba.

\section{G. Kesimpulan}

berdasarkan hasil penelitian dan pembahasan maka penulis dapat menarik kesimpulan sebagai berikut:

1. Break Even Point pada PT Kalbe Farma Tbk mengalami tingkatan yang tidak merata. Penurunan drastis terjadi di tahun 2014 dan ditahun selanjutnya terus mengalami penurunan dan di tahun 2016 mengalami kenaikan kembali.

2. Perencanaan Laba pada PT Kalbe Farma Tbk memperoleh hasil penjualan yang baik dari tahun 2012 sampai dengan 2016, hasil penjualan terus menaik dari tahun ke tahun dengan pendapatan laba yang juga ikut mengalami penaikan.

3. Pengaruh Break Even Point terhadap perencanaan Laba pada PT Kalbe Farma Tbk. Berdasarkan perhitungan statistic yang telah dilakukan, dilihat dari koefisien korelasi bahwa pengaruh Break Even Point terhadap laba mempunyai hubungan yang kuat (positif) serta pengaruh kuat, yaitu 0.80. jika dilihat dari perhitungan uji $\mathrm{t}$ bahwa besar pengaruh antara Break Even Point terhadap Laba terdapat hubungan yang tinggi (positif), yaitu secara persial $t$ hitung sebesar 2.31 sedangakan $t$ tabel 2.07. maka Ha diterima yang berarti ada pengaruh antara Break Even Point terhadap perencanaan laba.

\section{H. Daftar Pustaka}

Brigham,E.F. \& Houston,J.F. 2001. "Manajemen Keuangan”. Edisi kedelapan Jakarta: Erlangga. 
Edisi sebelas , Jakarta: Salemba Empat.

2010. "Dasar - Dasar Manajemen Keuangan".

Darsono \& Ashari. 2005. "Pedoman Praktis Memahami Laporan Keuangan”.

Yogyakarta: Andi.

Harahap, Sofyan S.2007. "Analisis Kritis atas Laporan Keuangan”. Edisi kesatu. Jakarta : PT. Raja Grafindo Persada

Horne,J.C.V \& Wachowicz, J.M 2005. "Prinsip - Prinsop Manajer Keuangan”.Edisi 12 (diterjemahkan oleh Fitriasari, D \&Kwary, D.A). Jakarta Salemba Empat.

Ikatan Akuntansi Indonesia. 2004. "Standar Akuntansi Keuangan”. Salemba Emapat.

Jumingan. 2006. “Analisis Laporan Keuangan”. Jakaarta: Bumi Aksara.

Kasmir, 2009. “Analisis Lapora Keuangan”. Jakarta: Rajawali Pers.

Mamduh, M. Hanafi. 2009. "Analisis Laporan Keuangan”. Yogyakarta : UPP STIM YKPN.

Mulyadi, 2001. "Balanced Scorecard : atau Manajemen Kontemporer Untuk Pelipatgandan Kinerja Keuangan Perusahaan". Yoarta. Salemba Empat.

Munawir, S. 2007. “Analisa Laporan Keuangan”. Edisi Keempat. Liberty.Yogyakarta.

2002. “Analisa Laporan Keuangan”. Liberty. Yogyakarta.

Nardi Sunardi (2017), "Determinan Kebijakan Utang serta Implikasinya terhadap Kinerja Perusahaan (Perusahaan yang tergabung dalam index LQ.45 yang terdaftar di Bursa Efek Indonesia)" Jurnal Sekuritas (Saham, Ekonomi, Keuangan dan Investasi), ISSN (online) : 2581-2777 \& ISSN (print) : 2581-2696 , Vol.1, No.1, September 2017, Hal. 78-97.

Riyanto, Bambang. 2001. “Dasar - Dasar Pembelajaran Perusahaan”. BPFE. Yogyakarta.

Sartono, Agus. 2001. "Manajemen Keuangan Teori dan Aplikasi”. Edisi Keempat. Yogyakarta: Penerbit BPFE

Sawir, Agnes. (2005). "Analisis Kinerja Keuangan dan Perencanaan Keuangan Perusahaan”. PT Gramedia Pustaka Utama, Jakarta.

Sugiono, Arief. 2009. "Manajemen Keuangan untuk Praktisi Keuangan”. Jakarta: Grasindo.

Sugiyono. 2010. “ Metode Penelitian Kuantitatif , Kualitatif dan R\&D”. Bandung: Alfabeta. 